\title{
Column Studies on Chromium (VI) Adsorption onto Kala Jamun (Syzygiumcumini L.) Seed Powder (KSP)
}

\author{
Sumi Deka, Krishna Gopal Bhattacharyya
}

\begin{abstract}
This paper evaluate the industrial use of Kala Jamun (Syzygiumcumini L.) Seed powder (KSP) for the continuous adsorption of $\mathrm{Cr}(\mathrm{VI})$ in a column adsorption process. Adsrption of $\mathrm{Cr}(\mathrm{VI})$ onto Kala jamun Seed Powder have been examined with the variation of (a) bed depth of the adsorbents, (b) flow rate of the adsorbents and (c) $\mathrm{Cr}(\mathrm{VI})$ concentration. The results showed that both the adsorption and the regeneration of the $\mathrm{Cr}(\mathrm{VI})$ onto Kala Jamun (Syzygiumcumini L.) seed Powder (KSP) can effectively occur in the column mode of adsorption. On increasing the bed depth, the adsorption of $\mathrm{Cr}(\mathrm{VI})$ onto KSP increases whereas on increasing the flow rate and the $\mathrm{Cr}(\mathrm{VI})$ concentration of KSP adsorption decreases. The results of the column studies were also fitted to Bed Depth Service Time (BDST) model. The BDST model was appropriate for designing the column for industrial purpose.
\end{abstract}

Keywords - KSP, Cr(VI), bed-depth-service-time, continuous adsorption.

\section{INTRODUCTION}

Chromium is considered as one of the top sixteen toxic pollutants because of its carcinogenic characteristics for humans [1]. The permissible limit for chromium for drinking water is $0.1 \mathrm{mg} / \mathrm{L}$ (as total chromium) according to US EPA standard [2]. Chromium is released into the environment by both natural and anthropogenic sources.

Wastewater treatment is one of the major problems that must be dealt with in everyday life. In order to reduce the severe problems caused by water pollution, many countries and environmental protection authorities are continually restricting the use of chemicals as well as tightening on the discharge limits. Consequently, wastewaters containing toxic materials such as dyestuffs, organic pollutants and metal ions must be carefully treated before discharged. Adsorption is one of the most cost effective and efficient technologies used in wastewater treatment while activated carbon has been one of the most widely used adsorbents for adsorption processes in wastewater treatment.

In recent years, the need for safe and economical methods for the elimination of heavy metals from contaminated waters has necessitated research interest towards the production of low cost alternatives. During the past few years, the decreasing

Sumi Deka, Gauhati University, India

Krishna Gopal Bhattacharyya, Gauhati University, India availability and rising production costs have led to sharp price rises for activated carbon and the prices of coal based grade has risen by $80 \%$ between the beginning of 2007 and mid2008 [3]. Despite its extensive use in the water and wastewater treatment industries, activated carbon remains as expensive materials. A major drawback with precipitation is sludge production. Ion- exchange is considered as a better alternative technique for such purpose. However, it is not economically appealing because of high operational cost. These high technology processes have significant disadvantages, including incomplete metal removal, requirement for expensive equipments and monitoring system, high reagent and energy requirement system, or generation of toxic sludge or other waste products that require disposal [4]. The low cost agricultural waste by-products such as sugarcane bagasse $[5,6,7,8,9,10]$, rice husk $[11,12,13,14,15]$, sawdust $[16,17,18]$, coconut husk [5,19], oil palm shell [20], neem bark [21], etc, for the elimination of heavy metals from wastewater have been investigated by various researchers. Cost is an important parameter for comparing the sorbent materials. However cost information is seldom reported and expense of individual sorbents varies depending on the degree of processing required and local availability.

The present work investigates the possible industrial uses of Kala Jamun (Syzygiumcumini L.)Seed powder as biosorbent for the column studies of adsorption with the variation of bed depth, flow rate and $\mathrm{Cr}(\mathrm{VI})$ concentration .

\section{EXPERIMENTAL WORK}

Experiments were carried out to investigate the parameters for the optimization of the extraction of $\mathrm{Cr}(\mathrm{VI})$ from the sample solution by using electronic balance, $\mathrm{pH}$ meter (with glass electrode) , Electric grinder, UV1800,Shimadzu.UV-Spectrophotometer.

\section{MATERIALS AND METHODS}

The Kala Jamun Seeds were collected from Nabagraha Silpukhuri, Guwahati. The matured seeds were washed with distilled water and dried in an oven at $105^{\circ} \mathrm{C}$ overnight. Dried seeds were grind to fine powder in an electric grinder.

A stock solution containing 1000ppm of $\mathrm{Cr}(\mathrm{VI})$ was prepared using $\mathrm{K}_{2} \mathrm{Cr}_{2} \mathrm{O}_{7}$ in distilled water. All the chemicals used were of analytical grade. Successive dilutions of stock 
solutions were carried out to set up standard solutions ranging 50-100 ppm.

Column studies are efficient in learning the behavior of the adsorption process. In the method, the adsorbate solution is allowed to flow continuously through a fixed bed of the adsorbent solid. Rate of flow, concentration of the solute and the height of the adsorbent bed can be changed. Adsorption is monitored by the continuous measurement of the solute concentration in the eluent with respect to the volume flowing out of the column or time. Column efficiency is described by the breakthrough curve, which is obtained by plotting $\mathrm{C} / \mathrm{Co}(\mathrm{C}$ concentration of the adsorbate solute in the eluent, Co the initial concentration when the feed enters the column) against time or volume coming out [22]. Breakthrough curve may vary for different environment. Generally it occurs as " $\mathrm{S}$ " shaped curve. A particular breakthrough (say, 95\%) occurs at a certain time $t_{b}$, when the eluent concentration reaches $95 \%$ of the initial concentration.

The capacity of the column was calculated with the help of the equations, (1) and (2) given by Treybal in 1980 to remove the adsorbate molecules.

Breakthrough capacity $($ at $50 \%)=$ adsorbate taken up by the adsorbent bed in $\mathrm{mg}$ ] / [Bed mass of the adsorbent in $\mathrm{g}$ ] $(1)=[$ Time of breakthrough (at $50 \%$ ) (h) $x$ Rate of flow in L/h $\mathrm{x}$ Concentration of feed in $\mathrm{mg} / \mathrm{L}$ ] / [Bed mass of the adsorbent in

(2)The column adsorption experiments are carried out for different bed height, flow rate and concentration of $\mathrm{Cr}$ (VI) solution, as follows:

(a) Initial Concentration of aqueous $\mathrm{Cr}$ (VI) solution in $\mathrm{mg} / \mathrm{L}$ :

50, 80 and 100 .

(b) Bed height in $\mathrm{cm}: 1.4,2.0$ and 2.6.

(c) Flow rate in $\mathrm{mL} / \mathrm{min}: 2.3,4.9$ and 8.4 of KSP

For desorption and regeneration studies, $0.1 \mathrm{~N} \mathrm{NaOH}$ was used with a bed depth of $1.4 \mathrm{~cm}$ and flow rate of 1.8 for KSP.

\section{RESUlTS AND DiscUSSIONS}

\section{A. Effect of bed depth}

The experimental conditions to investigate the effects of bed depth on $\mathrm{Cr}(\mathrm{VI})$ adsorption and therefore, on the breakthrough curve are given in Table 1.

TABLE I EXPERIMENTAL CONDITIONS FOR STUDYING EFFECTS OF BED DEPTH ON CR(VI) ADSORPTION

\begin{tabular}{|c|l|l|l|l|}
\hline Adsorbent & $\begin{array}{l}\text { Bed } \\
\text { Depth } \\
(\mathrm{cm})\end{array}$ & $\begin{array}{l}\text { Amount } \\
\text { required } \\
(\mathrm{g})\end{array}$ & $\begin{array}{l}\text { Flow Rate } \\
(\mathrm{mL} / \mathrm{min})\end{array}$ & $\begin{array}{l}\text { Concentration } \\
(\mathrm{mg} / \mathrm{L})\end{array}$ \\
\hline $\mathrm{KSP}$ & $\begin{array}{l}1.4, \\
2.0,2.6\end{array}$ & $\begin{array}{l}1.0, \quad 1.5, \\
2.0\end{array}$ & 2.3 & 50 \\
\hline
\end{tabular}

The breakthrough curves, obtained for $\mathrm{Cr}(\mathrm{VI})$ adsorption, are given in Figs.1for KSP. The breakthrough curves have similar patterns in all the cases, with S-shaped appearance.

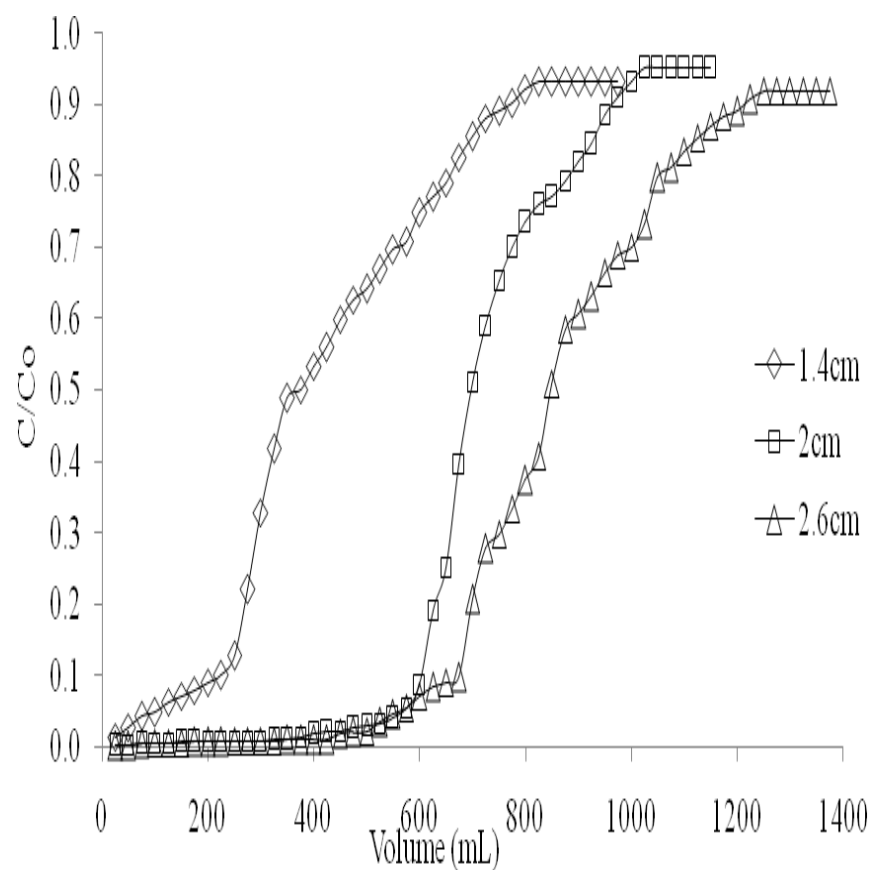

Fig 1 Effects of bed depth on $\mathrm{Cr}(\mathrm{VI})$ adsorption on KSP at $303 \mathrm{~K}$ (flow rate $2.3 \mathrm{~mL} / \mathrm{min}$, feed concentration $50 \mathrm{mg} / \mathrm{L}$ )

With increase in bed depth, the breakthrough volume and time at both (90\% and 50\%), showed an increase indicating that with a larger bed depth of the biosorbents, it would be possible to treat large volumes of $\mathrm{Cr}(\mathrm{VI})$-contaminated water with the biosorbents used in this work.

TABLE II BREAKTHROUGH VOLUMES AND TIMES AT 90\% AND 50\% AT DIFFERENT BED DEPTHS. [BV BREAKTHROUGH VOLUME, ADCAP ADSORPTION CAPACITY]

\begin{tabular}{|c|c|c|c|c|c|c|}
\hline \multirow[b]{2}{*}{$\begin{array}{l}\text { Bed } \\
\text { Depth } \\
(\mathrm{cm})\end{array}$} & \multicolumn{3}{|c|}{ Breakthrough at $90 \%$} & \multicolumn{3}{|c|}{ Breakthrough at $50 \%$} \\
\hline & $\begin{array}{l}\text { BV } \\
(\mathrm{mL})\end{array}$ & $\begin{array}{l}\text { TIME } \\
\text { (min) }\end{array}$ & $\begin{array}{l}\text { AdC } \\
\text { ap } \\
(\mathrm{mg} / \\
\mathrm{g}) \\
\end{array}$ & $\begin{array}{l}\text { BV } \\
(\mathrm{mL})\end{array}$ & $\begin{array}{l}\text { TIME } \\
\text { (min) }\end{array}$ & $\begin{array}{l}\mathrm{AdCa} \\
\mathrm{p} \\
(\mathrm{mg} / \mathrm{g})\end{array}$ \\
\hline $\mathrm{K}^{1.4}$ & 775.0 & 337.0 & 38.7 & 375.0 & 163.0 & 18.8 \\
\hline S 2.0 & 975.0 & 423.9 & 32.5 & 700.0 & 304.3 & 23.3 \\
\hline $\begin{array}{l}P \\
P\end{array}$ & 1225.0 & 532.6 & 30.6 & 850.0 & 369.6 & 21.3 \\
\hline
\end{tabular}

In all the cases, $\mathrm{Cr}(\mathrm{VI})$ adsorption capacities of the columns are different for $90 \%$ and $50 \%$ breakthroughs, but the values differ very little for different amounts of a biosorbent. This is also along the expected lines as the amount adsorbed per unit mass should be the same for different bed depths of the same material. However, the adsorption capacities at $90 \%$ breakthrough are definitely larger than those at $50 \%$ breakthrough.

\section{B. Effect of the Flow Rate}

The experimental conditions to investigate the effects of flow rates on $\mathrm{Cr}(\mathrm{VI})$ adsorption are given in Table 3 . 
TABLE III EXPERIMENTAL CONDITIONS FOR THE STUDY OF THE EFFECTS OF FLOW RATE

\begin{tabular}{|l|c|l|c|}
\hline Adsorbent & $\begin{array}{l}\text { Bed Depth } \\
(\mathrm{cm})\end{array}$ & $\begin{array}{l}\text { Flow Rate } \\
(\mathrm{mL} / \mathrm{min})\end{array}$ & $\begin{array}{l}\mathrm{Cr}(\mathrm{VI}) \\
(\mathrm{mg} / \mathrm{L})\end{array}$ \\
\hline KSP & 1.4 & $2.3,4.9$ and 8.4 & 50 \\
\hline
\end{tabular}

The breakthrough curves for all the four different adsorbents having $1.4 \mathrm{~cm}$ bed depth and $50 \mathrm{mg} / \mathrm{L}$ concentration of $\mathrm{Cr}(\mathrm{VI})$ are given in Figs. 2 for KSP.

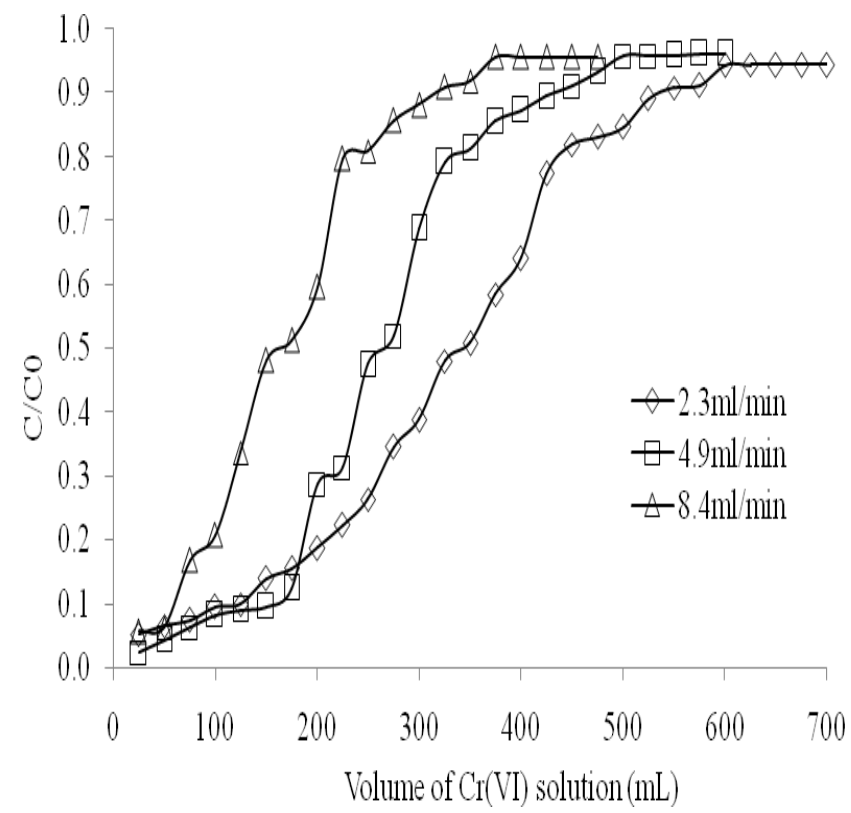

Fig. 2. Effects of flow rate on $\mathrm{Cr}(\mathrm{VI})$ adsorption on $\mathrm{KSP}$ at $303 \mathrm{~K}$ (bed depth $1.4 \mathrm{~cm}$, feed concentration $50 \mathrm{mg} / \mathrm{L}$ )

At lower flow rate of the effluent, the breakthrough curve is steeper indicating increased adsorption of $\mathrm{Cr}(\mathrm{VI})$. This is also seen from the data in Table 4 which shows that adsorption increases when the flow rate is low.

TABLE IV BREAKTHROUGH VOLUMES AND TIMES AT $90 \%$ AND $50 \%$ AT DIFFERENT FLOW RATES

\begin{tabular}{|c|c|c|c|c|c|c|c|}
\hline \multirow{2}{*}{\multicolumn{2}{|c|}{$\begin{array}{l}\text { Flow rate } \\
(\mathrm{mL} / \mathrm{min})\end{array}$}} & \multicolumn{3}{|c|}{ Breakthrough at $90 \%$} & \multicolumn{3}{|c|}{ Breakthrough at $50 \%$} \\
\hline & & \multirow{2}{*}{$\begin{array}{l}\begin{array}{l}\mathrm{BV} \\
(\mathrm{mL})\end{array} \\
5500\end{array}$} & $\begin{array}{l}\text { TIME } \\
\text { (min) }\end{array}$ & $\begin{array}{l}\text { AdCa } \\
\mathrm{p} \\
(\mathrm{mg} / \mathrm{g} \\
)\end{array}$ & \multirow{2}{*}{$\begin{array}{l}\text { BV } \\
(\mathrm{mL})\end{array}$} & \multirow{2}{*}{$\begin{array}{l}\text { TIME } \\
\text { (min) } \\
152.2\end{array}$} & \multirow{2}{*}{$\begin{array}{l}\mathrm{AdCa} \\
\mathrm{p} \\
(\mathrm{mg} / \mathrm{g})\end{array}$} \\
\hline \multirow{3}{*}{$\begin{array}{l}\text { KS } \\
\text { P }\end{array}$} & 2.3 & & 239.1 & 27.5 & & & \\
\hline & 4.9 & 450.0 & 91.8 & 22.5 & 275.0 & 56.1 & 13.8 \\
\hline & 8.4 & 325.0 & 38.7 & 16.3 & 175.0 & 20.8 & 8.8 \\
\hline
\end{tabular}

For the biosorbents, KSP the breakthrough time, breakthrough volume and adsorption capacities at 50 and $90 \%$ breakthrough points decrease at increasing flow rates. The results show that at lowest flow rate, the adsorption of the column perfects well. At higher flow rate, the time of contact between the adsorbent bed and $\mathrm{Cr}(\mathrm{VI})$ ions is relatively short, which results in decrease in adsorption capacity.

\section{Effects of Cr(VI) Concentration}

The effects of $\mathrm{Cr}(\mathrm{VI})$ concentration on its adsorption in a continuous column mode are illustrated with the help of breakthrough curves (plots of $\mathrm{Ct} / \mathrm{Co}$ vs. volume) in Figs. 3 for KSP. The experimental conditions for this column study are given in Table 5.

TABLE V EXPERIMENTAL CONDITIONS FOR COLUMN ADSORPTION OF
\begin{tabular}{|l|ll|l|l|}
\hline & $\begin{array}{l}\text { Bed (VI) AT DIFFERENT CONCENTRATIONS } \\
(\mathrm{cm})\end{array}$ & $\begin{array}{l}\text { Flow Repth Rate } \\
(\mathrm{mL} / \mathrm{min})\end{array}$ & $\begin{array}{l}\text { Concentration } \\
(\mathrm{mg} / \mathrm{L})\end{array}$ \\
\hline KSP & 1.4 & 2.3 & $50,80,100$ \\
\hline
\end{tabular}

The breakthrough volumes and times are given in Table 6 for all the adsorbent KSP. The breakthrough curves become slightly steeper at higher $\mathrm{Cr}(\mathrm{VI})$ concentration. At higher $\mathrm{Cr}(\mathrm{VI})$ concentration, the column may be saturated quickly resulting in lower breakthrough time and volume.

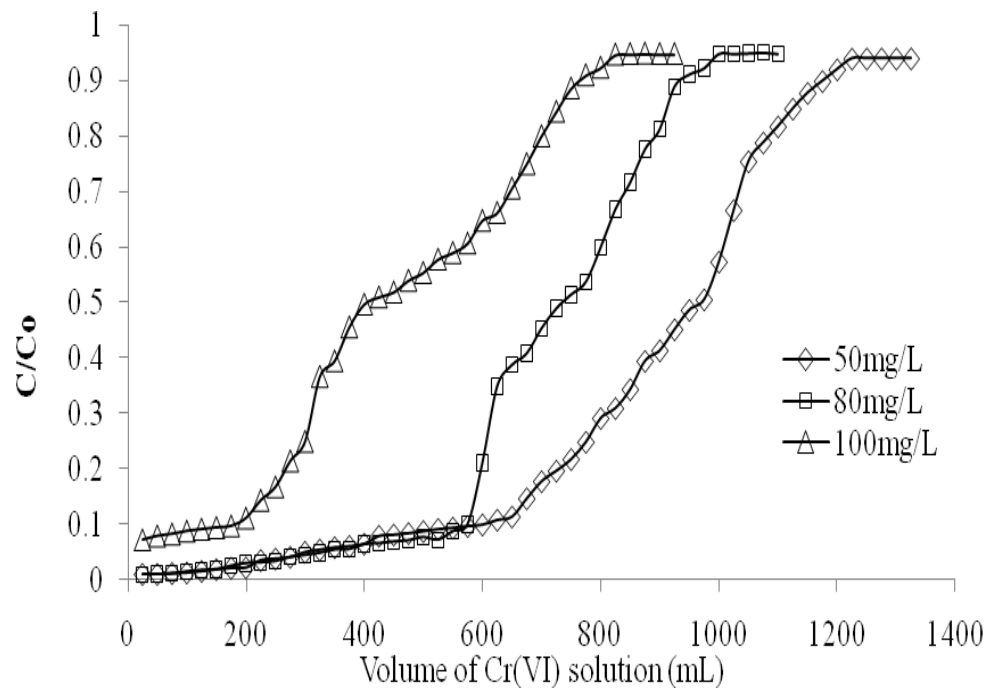

Fig. 3. Effects of $\mathrm{Cr}(\mathrm{VI})$ concentration on adsorption in a KSP column at $303 \mathrm{~K}$ (bed depth $1.4 \mathrm{~cm}$, flow rate $2.3 \mathrm{~mL} / \mathrm{min}$ )

TABLE VI BREAKTHROUGH VOLUMES AND TIMES AT 90\% AND 50\% AT DIFFERENT CR(VI) CONCENTRATION.

\begin{tabular}{|c|c|c|c|c|c|c|c|}
\hline \multirow[b]{2}{*}{$\begin{array}{l}\text { Biosorbe } \\
\mathrm{nt}\end{array}$} & \multirow[b]{2}{*}{$\begin{array}{l}\mathrm{Cr}( \\
\mathrm{VI}) \\
(\mathrm{mg} \\
/ \mathrm{L})\end{array}$} & \multicolumn{3}{|c|}{ Breakthrough at $90 \%$} & \multicolumn{3}{|c|}{ Breakthrough at $50 \%$} \\
\hline & & $\begin{array}{l}\text { BV } \\
(\mathrm{mL})\end{array}$ & $\begin{array}{l}\text { TIM } \\
\text { E } \\
(\min \\
)\end{array}$ & $\begin{array}{l}\text { AdC } \\
\text { ap } \\
\text { (mg/ } \\
\text { g) }\end{array}$ & $\begin{array}{l}\text { BV } \\
(\mathrm{mL})\end{array}$ & $\begin{array}{l}\text { TIME } \\
(\mathrm{min})\end{array}$ & $\begin{array}{l}\text { AdC } \\
\text { ap } \\
\text { (mg/ } \\
\text { g) }\end{array}$ \\
\hline \multirow{3}{*}{ KSP } & 50 & 1175 & $\begin{array}{l}510 . \\
9\end{array}$ & 58.8 & 975.0 & 423.9 & 48.8 \\
\hline & 80 & 950 & 413. & 76.0 & 750.0 & 326.1 & 60.0 \\
\hline & 100 & 775 & $\begin{array}{l}337 . \\
0\end{array}$ & 77.5 & 425.0 & 184.8 & 42.5 \\
\hline
\end{tabular}


It is found that the breakthrough time and breakthrough volume at 50 and $90 \%$ breakthrough points decreases with increasing $\mathrm{Cr}(\mathrm{VI})$ concentration for all the four biosorbents

\section{Application of Bohart-Adam Model}

One of the successful, widely used and common model to explain column adsorption in a fixed bed process is the breakthrough service time (BDST) model (Bohart and Adams, 1920). The BDST model at various percentages of breakthrough points is based on the estimation of the characteristic parameters like maximum adsorption capacities (No) and the kinetic constant (K). The isoremoval lines or the BDST plots are obtained by plotting of the bed depth against the service time. The breakthrough concentrations considered are 20, 40, 60 and $80 \%$. The plots for the biosorbent KSP are given in Figs. 4 for KSP. The coefficients of the BDST model were calculated from the slope and the intercept of the BDST plots. The linear flow rate is $1.495 \mathrm{~cm} / \mathrm{min}$ for $\mathrm{KSP}$.

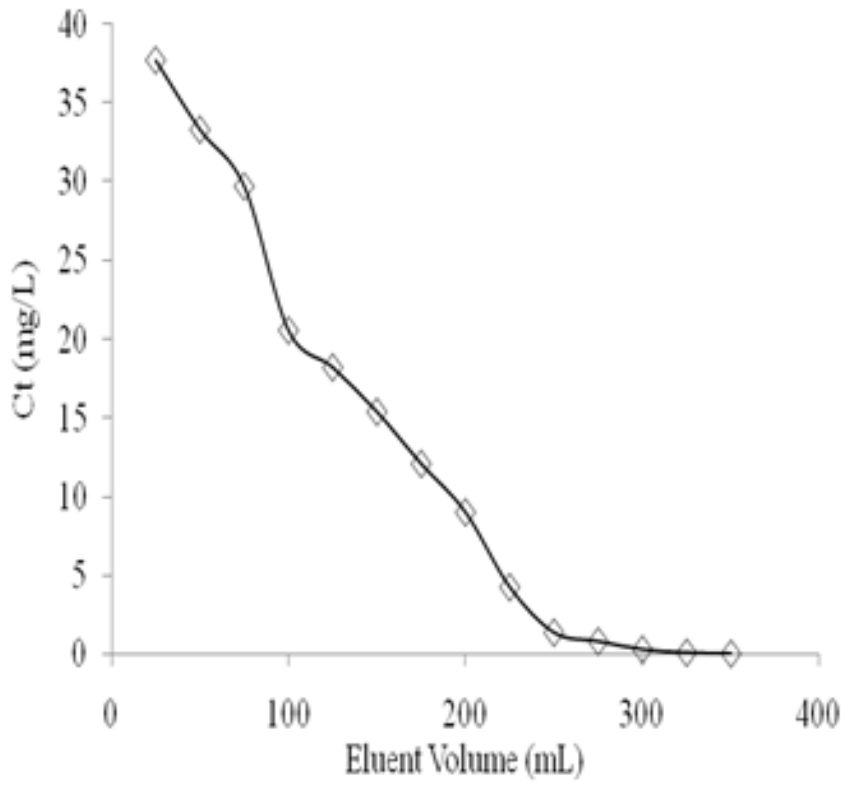

Fig. 4. Iso-removal lines for $\mathrm{Cr}(\mathrm{VI})$ adsorption on $\mathrm{KSP}$ at $303 \mathrm{~K}$ (flow rate $2.3 \mathrm{~mL} / \mathrm{min}$, feed concentration $50 \mathrm{mg} / \mathrm{L}$ ).

TABLE VII THE BDST MODEL PARAMETERS FOR COLUMN SORPTION OF $\mathrm{CR}(\mathrm{VI})$ ON KSP

\begin{tabular}{llllll}
\hline $\begin{array}{l}\text { Breakt } \\
\text { hroug } \\
\text { h } \\
\text { point } \\
(\%)\end{array}$ & Slop & Intercept & $\begin{array}{l}\text { Adsorption } \\
\text { capacity, } N_{0} \\
(\mathrm{~g} / \mathrm{L})\end{array}$ & $\begin{array}{l}\mathrm{K} \\
(\mathrm{L} / \mathrm{g} / \mathrm{h})\end{array}$ & $\begin{array}{l}\text { Regress } \\
\text { ion } \\
\text { coeffici } \\
\text { ent }(\mathrm{r})\end{array}$ \\
\hline 20 & 97.8 & 43.53 & 7.29 & 38.2 & 0.93 \\
40 & 108.7 & -279 & 8.10 & -1.7 & 0.97 \\
60 & 97.8 & -481.6 & 7.29 & 1.0 & 0.99 \\
80 & 86.95 & -583.2 & 6.48 & 2.9 & 0.99 \\
\hline
\end{tabular}

All the BDST plots at breakthrough points of 20, 40, 60 and $80 \%$ are linear in nature. The validity of the BDST model for all the biosorbent KSP for $\mathrm{Cr}(\mathrm{VI})$ biosorption is shown by the mean correlation coefficient (r) which has value of 0.97 for KSP.

\section{V.DESORPTION AND REGENERATION STUDY}

The selected flow rates of all the four biosorbents for the desorption study are given in Table 8

TABLE VIII THE FLOW RATES SELECTED FOR DESORPTION

\begin{tabular}{|c|c|c|}
\hline Adsorbent & Bed depth $(\mathrm{cm})$ & $\begin{array}{l}\text { Flow Rate of eluent } \\
(\mathrm{mL} / \mathrm{min})\end{array}$ \\
\hline KSP & 1.4 & 1.8 \\
\hline
\end{tabular}

For desorption, aqueous solution of $\mathrm{NaOH}$ was used. Works by a number of workers have indicated the use of $\mathrm{NaOH}$ in desorption of $\mathrm{Cr}(\mathrm{VI})$ ions.

The desorption curves for KSP columns are shown in Figs 5. The volume and the time for complete desorption of $\mathrm{Cr}(\mathrm{VI})$ ions are shown in Table 9.

Fig. 5. Desorption of $\mathrm{Cr}(\mathrm{VI})$ from $\mathrm{Cr}(\mathrm{VI})$-loaded KSP column at $303 \mathrm{~K}$ with aqueous $0.1 \mathrm{~N} \mathrm{NaOH}$ (bed depth $1.4 \mathrm{~cm}$, flow rate 1.8 $\mathrm{mL} / \mathrm{min}$ ).

TABLE IX TIME AND VOLUME OF $0.1 \mathrm{~N}$ NAOH REQUIRED FOR COMPLETE DESORPTION OF CR(VI) IONS FROM CR(VI)-ADSORBED COLUMNS.

\begin{tabular}{|l|l|l|l|l|}
\hline Biosorbent & $\begin{array}{l}\text { Bed } \\
\text { depth } \\
(\mathrm{cm})\end{array}$ & $\begin{array}{l}\text { Flow rate } \\
(\mathrm{mL} / \mathrm{min})\end{array}$ & $\begin{array}{l}\text { Exhaustion } \\
\text { time }(\mathrm{min})\end{array}$ & $\begin{array}{l}\mathrm{NaOH} \\
\text { required } \\
(\mathrm{mL})\end{array}$ \\
\hline $\mathrm{KSP}$ & 1.4 & 1.8 & 194.4 & 350 \\
\hline
\end{tabular}

From the results, it can be concluded that a small volume of very dilute $(0.1 \mathrm{~N})$ aqueous $\mathrm{NaOH}$ is needed for total desorption of $\mathrm{Cr}(\mathrm{VI})$ ions $(50 \mathrm{mg} / \mathrm{L})$ from columns of bed depth $1.4 \mathrm{~cm}$ packed with the biosorbent $\mathrm{KSP}$ and concentration.

\section{CONCLUSIONS}

Column adsorption of $\mathrm{Cr}(\mathrm{VI})$ on the four adsorbent KSP was found to be dependent on bed depth, flow rate and $\mathrm{Cr}(\mathrm{VI})$ concentration. Column adsorption at constant feed flow rate and $\mathrm{Cr}(\mathrm{VI})$ concentration, but varying bed depth of $1.4,2.0$ and $2.6 \mathrm{~cm}$, showed that the adsorption capacity of the biosorbent KSP decreased with increasing bed depth. When the flow rate of $\mathrm{Cr}(\mathrm{VI})$ feed solution was varied but the bed depth and the solution concentration were kept constant, $\mathrm{Cr}(\mathrm{VI})$ adsorption capacity of the biosorbent KSP decreased with increasing flow rate. With variation of solution concentration $(50,80$ and $100 \mathrm{mg} / \mathrm{L})$, keeping bed depth and the flow rate constant, $\mathrm{Cr}(\mathrm{VI})$ adsorption capacity of the biosorbent KSP decreased with increasing solution concentration. The Bohart Adams model could be successfully applied to $\mathrm{Cr}(\mathrm{VI})$ adsorption by the biosorbent KSP in the dynamic column sorption mode. Adsorbed $\mathrm{Cr}(\mathrm{VI})$ ions from 
the respective adsorbent bed could be successfully desorbed and the bed could be regenerated using $0.1 \mathrm{~N} \mathrm{NaOH}$ solution. As a whole, the biosorbent KSP is good adsorber of $\mathrm{Cr}(\mathrm{VI})$ from aqueous solution and therefore, could be exploited for removing $\mathrm{Cr}(\mathrm{VI})$ from industrial effluents and other wastewater. The column study further showed that the biosorbent KSP have sufficiently large breakthrough volumes at $90 \%$ removal of $\mathrm{Cr}(\mathrm{VI})$.

\section{REFERENCES}

[1] J.L.G Torresdey, K.J. Tiemann, V. Armendariz, Characterization of $\mathrm{Cr}(\mathrm{VI})$ binding and reduction to $\mathrm{Cr}(\mathrm{III})$ by the agricultural byproducts of avena monida (Oat) biomass, J.Hazard. Mater. 80(1-3) (2000) 175188.

https://doi.org/10.1016/S0304-3894(00)00301-0

[2] Drinking Water Standard, Envirnmental Protection Agency, Available from:http/www.epa.gov/safewater/contaminants/index.html.

[3] Anon, The Economics of Activated Carbon, 8th ed., Roskill Information Services Ltd., London, 2008.

[4] Z. Aksu, F. Gonen, Z. Demircan, Biosorption of chromium(VI) ions by Mowital B30H resin immobilized activated sludge in a packed bend: Comparison with granular activated carbon, Process Biochem. 38 (2002) 175-86. https://doi.org/10.1016/S0032-9592(02)00053-5

[5] S. Chand, V.K. Aggarwal, P. Kumar, Removal of hexavalent chromium from the waste water by adsorption, Indian J. Environ. Health. 36(3) (1994) 151-58.

[6] D. Mohan, K.P. Singh, Single and multi component adsorption of cadmium and zinc using activated carbon derived from bagasse - an agricultural waste, Water Research. 36 (2002) 2304-2318. https://doi.org/10.1016/S0043-1354(01)00447-X

[7] N.A. Khan, S.I. Ali, S. Ayub, Effect of $\mathrm{pH}$ on the removal of $\mathrm{Cr}(\mathrm{VI})$ by sugarcane baggase, Science and Tech. 6 (2001) 13-19.

[8] S. Ayub, S.I. Ali, N.A. Khan, R.A.K. Rao, Treatment of Indian J. Environ. Health. wastewater by agricultural waste, Environmental Protection Control Journal. 2(1) (1998) 5-8.

[9] S. Ayub, S.I. Ali, N.A. Khan, Study on the removal of $\mathrm{Cr}(\mathrm{VI})$ by sugarcane Baggase from wastewater, Pollution Research Journal. 2(2) (2001) 233-37.

[10] S. Ayub, S.I. Ali, N.A. Khan, Adsorption studies on the low cost adsorbent for the removal of $\mathrm{Cr}(\mathrm{VI})$ from electroplating wastewater, Environmental Protection Control Journal. 5(6) (2002) 10-20.

[11] K. Srinivasan, N. Balasubramaniam, T.V. Ramakrishna, Studies on chromium removal by rice husk carbon, Indian J. Environ. Health. 30(4) (1998) 376-87.

[12] E. Munaf, R. Zein, The use of rice husk for removal of toxic metals from wastewater, Environmental Technology. 18 359-62. https://doi.org/10.1080/09593331808616549

[13] M. Ajmal, R.A.K. Rao, S. Anwar, J. Ahmad, R. Ahmad, Adsorption studies on rice husk: removal and recovery of $\mathrm{Cd}(\mathrm{II})$ from wastewater, Bioresource Tech. 86 (2003) 147-49 https://doi.org/10.1016/S0960-8524(02)00159-1

[14] R. Suemitsu, R. Venishi, I. Akashi, M. Nakano, The use of dyestufftreated rice hulls for removal of heavy metals from wastewater, Journal of Applied Polymer Science. 31 (1986) 75-83. https://doi.org/10.1002/app.1986.070310108

[15] N.A. Khan, M.G. Shaaban, Z. Jamil, Chromium removal from wastewater through adsorption process, Proc. UM. Research Seminar 2003 Organised by Institute of Research Management and Consultancy (IPPP) University of Malaya, Kuala Lumpur.

[16] M. Ajmal, R.A.K. Rao, B.A. Siddiqui, Studies on removal and recovery of $\mathrm{Cr}(\mathrm{VI})$ from electroplating wastes, Water Res. 30(6) (1996) 1478-82. https://doi.org/10.1016/0043-1354(95)00301-0

[17] K. Kadirvelu, M. Kavipriya, C. Karthika, M. Radhika, N. Vennilamani, S. Pattabhi, Utilization of various agricultural wastes for activated carbon preparation and application for the removal of dyes and metal ions from aqueous solution, Bioresource Tech. 87 (2003) $129-32$.

https://doi.org/10.1016/S0960-8524(02)00201-8
[18] K. Selvi, S. Pattabhi, K. Kadirvelu, Removal of chromium(VI) from aqueous solution by adsorption onto activated carbon, Bioresource Tech. 80 (2001) 87-89. https://doi.org/10.1016/S0960-8524(01)00068-2

[19] W.T. Tan, S.T. Ooi, C.K. Lee, Removal of chromium(VI) from solution by coconut husk and palm pressed fibre, Environmental Technology. 14 (1993) 277-82. https://doi.org/10.1080/09593339309385290

[20] N.A. Khan, M.G. Shaaban, MH.A. Hassan, Removal of heavy metal using an inexpensive adsorbent, Proc. UM Research Seminar 2003 organized by Institute of reseaech management and Consultancy(IPPP), University of Malaya, Kuala Lumpur.

[21] S. Ayub, S.I. Ali, N.A. Khan, Efficiency evaluation of neem (Azadirachta indica) bark in treatment of industrial wastew ater. Environmental Pollution Control Journal. 4 (2001) 34-38.

[22] J.C. Moreno-Piraján, D. Rangel, B. Amaya, E.M. Vargas, L. Giraldo, Scale up of a pilot plant for adsorption of heavy metals. J. Argent. Chem. Soc. 94 (2006) 71-82. 